\title{
PENGARUH PENERAPAN MODEL PEMBELAJARAN KOOPERATIF TIPE STAD TERHADAP HASIL BELAJAR SISWA
}

\author{
Rohman Arif \\ (SMPN 1 Sukodono) \\ dastaniarif@gmail.com
}

\begin{abstract}
Cooperative learning model Team Assisted Individualization is one approach that helps students to solve a creative problem-solving. The research was conducted at SMK NU Gresik. With the research subjects were students of class X MM SMK NU Gresik This study uses two cycles that each cycle has four stages: planning, implementation, observation phase, and the phase of reflection. Data collection method used is to use a subjective test in every cycle. Data in the form of student test results will then be analyzed descriptively to determine student mastery of learning outcomes in the classical style. From the results of the research activities that have been carried out for two cycles, and based on the discussion and analysis that has been carried out can be concluded that the application of cooperative learning model Team Assisted Individualization (TAI) to improve learning outcomes quadratic equation mathematics subject in class X-MM SMK NU Gresik 2012-2013 school year. It can be seen from the improvement of student learning in the classical mastery of each cycle, the prasiklus $57.5 \%$ to $72.5 \%$ in the first cycle, but has yet to achieve mastery in the classical learning. Then the deficiencies in the first cycle improvements held on the second cycle increased $87.5 \%$ to reach $15 \%$ of cycle I. In the second cycle students have achieved mastery in the classical so expect the teachers to consider using this learning model
\end{abstract}

Keywords: Team Assisted Individualization, mathematics learning achievements, quadratic equation

\section{PENDAHULUAN}

Pendidikan sebenarnya merupakan suatu rangkaian peristiwa yang kompleks. Peristiwa tersebut merupakan rangkaian kegiatan komunikasi antar manusia sehingga manusia itu bertumbuh sebagai pribadi yang utuh. Manusia bertumbuh melalui belajar, tidak dapat melepaskan diri dari mengajar. Kurikulum 2013 yang berlaku sekarang menuntut siswa agar selalu lebih aktif dalam belajar. Untuk memenuhi tuntutan itu, diperlukan pembelajaran matematika yang inovatif dan bermakna, tidak cukup hanya dengan mendengar, melihat dan mencatat apa yang ada di papan tulis dan apa yang yang didengar, tetapi harus melakukan aktivitas (membaca, bertanya, menjawab, berpendapat, mengerjakan, mengkomunikasikan, prestasi diskusi, dll).

Di sisi lain banyak fakta yang timbul jika guru menguasai materi dengan baik tapi tidak untuk proses penyampaian pembelajaran kepada peserta didik. Hal itu terjadi karena proses kegiatan belajar disampaikan dengan cara yang membosankan atau pembelajaran fokus bercerita (ceramah) tanpa ada timbal balik antara guru dengan peserta didik. Efek dari penggunaan metode ceramah yang berlangsung terus menerus adalah kreatifitas dan pengetahuan siswa yang minim dan akan berpengaruh pada prestasi hasil belajar siswa yang rendah Kegagalan dari rendahnya hasil belajar siswa dipengaruhi oleh proses pembelajaran yang tidak berjalan baik dan peserta didik yang masih minim belajar, motivasi belajar, konsentrasi belajar, kemampuan mengolah bahan belajar, kemampuan menyimpan perolehan hasil belajar, kemampuan menggali hasil belajar yang tersimpan, kemampuan berprestasi atau unjuk hasil belajar, rasa percaya diri siswa, intelegensi dan keberhasilan belajar, kebiasaan belajar, dan cita-cita siswa (Dimyati dan Mudjiono, 2006:260).

Dalam kegiatan pembelajaran diharapkan hasil pembelajaran siswa dapat meningkat dan kegiatan 
pembelajaran lebih bermakna.. Berdasarkan hasil penelitian menunjukkan bahwa hasil pembelajaran oleh rekan sebaya melalui pembelajaran kooperatif ternyata lebih efektif daripada pembelajaran oleh pengajar (Lie 2002).

Berdasarkan uraian diatas memecahkan masalah pendidikan diperlukan upaya penerapan strategi pembelajaran menggunakan model pembelajaran kooperatif tipe STAD (Student Teams Achvement Division) yaitu suatu pendekatan pembelajara kooperatif dimana siswa ditempatkan dalam suatu kelompok belajar yang beranggotakan 4-5 orang. Untuk menyelesaikan tugas-tugas pembelajaran menurut Slavin Nur (1999:19) dalam menyelesaikan tugasnya setiap anggota kelompok saling kerjasama dan membantu untuk memahami suatu bahan pelajaran.

Pengertian pembelajaran kooperatif tipe STAD (Students Team Achievemen Division)/dikembangkan oleh Robert Slavin dan teman-temannya di Universitas John Hopkin, dan merupakan pendekatan pembelajaran kooperatif yang paling sederhana. Guru yang mengunakan STAD juga mengacu kepada belajar kelompok siswa, dimana siswa belajar dalam kelompok kecil yang terdiri dari 4 - 5 orang siswa dengan tingkat kemampuan berfikir dan jenis kelamin berbeda.

Hasil belajar merupakan tolak ukur yang digunakan untuk menentukan tingkat keberhasilan siswa dalam mengetahui dan memahami suatu mata pelajaran, biasanya dinyatakan dengan nilai yang berupa huruf atau angka-angka. Hasil belajar dapat berupa keterampilan, nilai dan sikap setelah siswa mengalami proses belajar. Melalui proses belajar mengajar diharapkan siswa memperoleh kepandaian dan kecakapan tertentu serta perubahan-perubahan pada dirinya.

Dari penjelasan di atas, peneliti ingin mengetahui jawaban dari permasalahan, adakah pengaruh penerapan model pembelajaran Kooperatif tipe STAD terhadap hasil belajar siswa kelas VIII SMP 1 Sukodono tahun ajaran 2014/2015? yang hasilnya diharapkan dapat bermanfaat bagi guru matematika dalam mengembangkan kreatifitas dan pengetahuan peserta didik. Dengan demikian tujuan penelitian ini untuk mengetahui pengaruh penerapan pembelajaran Kooperatif tipe STAD terhadap hasil belajar siswa pokok bahasan fungsi kelas VIII SMPN 1 Sukodono tahun ajaran 2014/2015.

\section{METODE PENELITIAN}

Peneliti dalam hal ini memakai rancangan penelitian True Eksperimental Design yaitu bahwa sampel yang digunakan untuk eksperimen maupun sebagai kelompok kontrol diambil secara random dari populasi tertentu. Jadi cirinya adalah adanya kelompok kontrol dan sampel dipilih secara random.(Sugiyono, 2009:112) dengan menggunkan dua kelas yaitu kelas kontrol dan kelas ekperimen. Dengan desain ini peneliti ingin mengetahui sejauh mana pengaruh penerapan model pembelajaran kooperatif tipe STAD terhadap hasil belajar siswa pokok bahasan fungsi kelas VIII SMPN 1 Sukodono. Populasi dalam penelitian ini adalah semua siswa kelas VIII SMPN 1Sukodono tahun ajaran 2014/2015.

Sampel yang diambil adalah semua siswa kelas VIII I sebagai kelas kontrol dan siswa kelas VIII J sebagai kelas ekperimen. Peneliti menggunakan teknik pengambilan sampel secara Simple Random Sampling yaitu dikatakan simple (sederhana) karena pengambilan anggota sampel dari populasi dilakukan secara acak tanpa memperhatikan strata yang ada dalam populasi itu. (Prof. Dr. Sugiyono: 2011).. Sedangkan pengumpulan data dilakukan dengan cara pemberian tes.

Dalam penelitian ini, kelas ekperimen dan kelas kontrol diberikan langkah-langkah pembelajaran yang sama hanya berbeda pada pemberian model pembelajarannya. Di mana kelas ekperimen diberi model pembelajaran kooperatif tipe STAD untuk memahami materi dan dipertemuan akhir materi diberi tes.

Instrumen penelitian adalah semua alat yang digunakan untuk mengumpulkan, memeriksa, menyelidiki suatu masalah, atau mengumpulkan, mengolah, menganalisa dan menyajikan data-data secara sistematis serta objektif dengan tujuan memecahkan suatu persoalan atau menguji suatu hipotesis. Jadi semua alat yang bisa mendukung suatu penelitian disebut 
instrumen penelitian. Dalam penelitian ini menggunakan silabus, RPP (Rencana Pelaksanaan Pembelajaran), LKS (Lembar Kegiatan Siswa), dan naskah soal tes.

Pada tahap ini, peneliti menyiapkan perangkat pembelajaran yang terdiri dari silabus, RPP, bahan ajar, media pembelajaran, Lembar Kegiatan Siswa, dan instrumen. Peneliti juga menyiapkan soal tes yang digunakan untuk membandingkan hasil belajar siswa kelas eksperiman dan kelas kontrol di SMPN 1 Sukodono.

Dari hasil tes dua kelas tersebut yang akan digunakan sebagai perbandingan dan penelitian apakah ada pengaruh penerapan model pembelajaran Kooperatif tipe STAD terhadap hasil belajar siswa pokok bahasan fungsi kelas VIII SMPN 1 Sukodono tahun ajaran 2014/2015

\section{HASIL DAN PEMBAHASAN}

Teknik analisis data yang digunakan pada penelitian ini adalah menggunakan rumus uji-t. Teknik ini termasuk teknik Statistik Parametris yaitu suatu teknik analisis data yang hanya bisa digunakan pada penelitian dengan menggunakan sampel sebagai sumber data. Rumus statistic teknik analisis uji-t adalah sebagai berikut:

$$
t=\frac{\overline{X_{A}}-\overline{X_{B}}}{\left(\sqrt{\left.\frac{\left(\mathrm{n}_{A}-1\right) \mathrm{S}_{A}^{2}+\left(\mathrm{n}_{2}-1\right) \mathrm{S}_{B}^{2}}{\mathrm{n}_{A}+\mathrm{n}_{B}-2}\right) \sqrt{\frac{1}{\mathrm{n}_{A}}+\frac{1}{\mathrm{n}_{B}}}}\right.}
$$

Keterangan:

t hitung

$\bar{X}_{A}=$ Nilai rata-rata siswa kelas control

$\bar{X}_{B}=$ Nilai rata-rata siswa kelas eksperimen

$n_{A}=$ Banyak sampel siswa kelas control

$n_{A}=$ Banyak sampel siswa kelas eksperimen

$\mathrm{S}_{A}^{2}=$ Simpangan baku untuk siswa kelas kontrol

$\mathrm{S}_{B}^{2}=$ Simpangan baku untuk siswa kelas eksperimen

Nilai rata-rata siswa kelas kontrol

$=\frac{\sum X}{\sum N}=\frac{2,292}{32}=71,62$

Nilai rata-rata siswa kelas eksperimen $=\frac{\sum X}{\sum N}=\frac{2,649}{32}=82,78$
Setelah melakukan penghitungan dengan rumus diperoleh $\mathrm{S}_{A}^{2}=20,87$ dan $\mathrm{S}_{B}^{2}=35,94$

Hasil analisis uji-t dengan menggunakan rumus uji $t$ diperoleh nilai $t_{\text {hitung }}$ adalah $-6,30$ dan Nilai taraf signifikannya adalah 0,05 , maka $\mathrm{H}_{0}$ ditolak dan $\mathrm{H}_{1}$ diterima. Sehingga pengaruh dari penerapan model pembelajaran kooperatif tipe STAD dapat membantu meningkatkan hasil belajar matematika siswa.

Penelitian pengaruh penerapan model pembelajaran kooperatif tipe STAD terhadap hasil belajar siswa pokok bahasan fungsi kelas VIII SMPN 1 Sukodono menggunakan rancangan penelitian True Eksperimental Design yang penelitian dengan menggunkan dua kelas yaitu kelas kontrol dan kelas ekperimen. Jadi cirinya adalah adanya kelompok kontrol dan sampel dipilih secara random. Disini akan dikemukakan salah satu bentuk design true eksperimental yaitu Posttest Only Control Design. Dalam design ini terdapat dua kelompok yang masing-masing dipilih secara random. Kelompok pertama diberi perlakuan (X) dan kelompok yang satunya tidak.

Kelompok yang diberi perlakuan disebut kelompok eksperimen dan kelompok yang tidak diberi perlakuan disebut kelompok kontrol. Pengaruh adanya perlakuan (treatment) adalah (O1: O2). Kalau terdapat perbedaan yang signifikan antara kelompok eksperimen dan kontrol maka perlakuan yang diberikan berpengaruh secara signifikan. Untuk itu sampel yang diambil dari populasi harus betul-betul respresentatif (mewakili). Peneliti menggunakan teknik pengambilan sampel secara Simple Random Sampling yaitu dikatakan simple (sederhana) karena pengambilan anggota sampel dari populasi dilakukan secara acak tanpa memperhatikan strata yang ada dalam populasi itu. (Prof. Dr. Sugiyono: 2011).

Dengan sampel adalah semua siswa kelas VIII I (32 siswa) dan VIII J (32 siswa). Model pembelajaran Langsung diterapkan terhadap siswa kelas VIII I dengan materi fungsi selama tiga kali pertemuan (6 x 45 menit) yang jumlah siswanya sebanyak 32 sisiwa. Model pembelajaran kooperatif tipe STAD diterapkan terhadap 
siswa kelas VIII $\mathrm{J}$ atau kelas eksperimen pada materi fungsi selama tiga kali pertemuan (6 x 45 menit) yang jumlah siswanya sebanyak 32 sisiwa.

Dalam hal ini peneliti bertindak sebagai penyampai materi pelajaran atau dengan istilah lain sebagai guru. Kegiatan belajar mengajar mengacu pada Rencana Pelaksanaan Pembelajaran (RPP) yang telah di siapkan. Setelah kedua kelas menempuh proses pembelajaran selama tiga kali pertemuan kemudian akan dilaksanakan tes hasil belajar, dimana isi naskah tes untuk kedua kelas adalah sama. Setelah diberikan tes maka akan didapat suatu nilai. Kemudian dilakukan pelaksanaan entri data nilai hasil tes belajar siswa kedua kelas.

Hasil belajar siswa antara siswa kelas kontrol dan siswa kelas eksperimen, yang selanjutnya diolah dengan menggunakan Analisis Uji-t. Untuk memudahkan dalam penyajian data, maka penulis akan membuat beberapa langkah. Langkah-langkah yang dilakukan untuk Uji-t adalah sebagai berikut :

Ditentukanlah Ho dan $\mathrm{H} 1$ yaitu $\mathrm{H}_{0}: \mu_{A}=\mu_{B}$ (tidak ada pengaruh penerapan model pembelajaran kooperatif tipe STAD terhadap hasil belajar siswa pokok bahasan fungsi kelas VIII SMPN 1 Sukodono tahun ajaran 2014/2015), dan $\mathrm{H}_{1} \quad \mu_{A} \neq \mu_{B}$ dan pengaruh penerapan model pembelajaran kooperatif tipe STAD terhadap hasil belajar siswa pokok bahasan fungsi kelas VIII SMPN 1 Sukodono tahun ajaran 2014/2015). Nilai taraf signifikannya adalah 0,05 .

Hasil analisis uji-t dengan menggunakan rumus uji $t$ diperoleh nilai $t_{\text {hitung }}$ adalah $-6,30$, maka $\mathrm{H}_{0}$ ditolak dan $\mathrm{H}_{1}$ diterima. Sehingga pengaruh dari penerapan model pembelajaran kooperatif tipe STAD dapat membantu meningkatkan hasil belajar matematika siswa. Hasil penelitian ini didukung temuan penelitian La Ili (2007) pada jurnal matematika Universitas Negeri Surabaya. Hasil penelitiannya menunjukkan bahwa model pembelajaran kooperatif tipe STAD dapat meningkatkan hasil belajar siswa

Pembelajaran kooperatif tipe STAD merupakan pembelajaran yang menantang siswa untuk mencari solusi dari permasalahan dunia nyata sehingga diharapkan mereka dapat menyusun atau membentuk keterampilan secara berkelompok yaitu dalam pengetahuan, kreatifitasnya, komunikasi, dan meningkatkan kepercayaan dirinya.

\section{PENUTUP \\ Simpulan}

Berdasarkan hasil penelitian yang telah dilakukan oleh peneliti, maka peneliti dapat menyimpulkan bahwa ada pengaruh penerapan model pembelajaran kooperatif tipe STAD terhadap hasil belajar siswa pokok bahasan fungsi kelas VIII SMP Negeri 1 Sukodono tahun ajaran 2014/2015, hal ini dapat dilihat dari rata-rata nilai hasil belajar matematika siswa yang diajar dengan model pembelajaran kooperatif tipe STAD lebih tinggi dari hasil belajar rata-rata peserta didik yang diajar dengan pembelajaran konvensional pada materi Fungsi

Berdasarkan data yang diperoleh, rata-rata hasil belajar peserta didik kelas eksperimen (Kelas VIII J) adalah 82,78 sedangkan rata-rata hasil belajar peserta didik kelas control (Kelas VIII I) adalah 71,62. Oleh karena itu jelas adanya perbedaan hasil belajar antara kelas eksperimen dan kelas kontrol.. Hal ini telah dibuktikan oleh analisis hasil penelitian yang diuraikan pada bab IV yaitu berupa data yang telah diolah, sehingga didapat analisis data statistik yang di uji dengan menggunakan uji-t didapatkan $\mathrm{t}$ hitung sebesar $-6,30$ dengan taraf signifikan $0.05 \quad\left(t_{\text {tabel }}=2,0322\right.$ dan $-2,0322$ ) dengan demikian $t_{\text {hitung }}<t_{\text {tabel }}$ yang disimpulkan H0 ditolak dan H1 diterima, ada pengaruh penerapan model pembelajaran kooperatif tipe STAD terhadap hasil belajar siswa pokok bahasan fungsi kelas VIII SMPN 1 Sukodono.

Dari hasil penelitian dan hipotesa ini maka peneliti dapat menyimpulkan bahwa "ada pengaruh penerapan model pembelajaran kooperatif tipe $\mathrm{STA} D$ terhadap hasil belajar siswa pokok bahasan fungsi kelas VIII SMPN 1 Sukodono".

\section{Saran}


Berdasarkan temuan penelitian ini, penulis memberikan saran sebagai berikut:

1. Diharapkan guru dapat menggunakan model pembelajaran kooperatif tipe STAD dengan baik, lebih inovatif dalam hal menggunakan metode di dalam pembelajaran, supaya pembelajaran matematika menjadi suatu pembelajaran yang menyenangkan dan bermakna.

2. Diharapkan peserta didik sebagai generasi yang cerdas dan penerus bangsa dapat mengubah sikap untuk lebih aktif, kreatif dan kritis untuk mencapai prestasi dan hasil belajar yang optimal.

Bagi pembaca, dapat memberikan khasanah dan wawasan pengetahuan tentang proses pembelajaran di dalam dunia pendidikan.

\section{DAFTAR PUSTAKA}

Arikunto, Suharsimi. 2010. Prosedur Penelitian: Suatu Pendekatan Praktik. Jakarta: Rineka Cipta

Dimyati, Dr dan Mudjiono, Drs. 2006. Belajar dan Pembelajaran. Jakarta: PT Rineka Cipta

Slavin dkk. 1995. Cooperative Learning, Research and Practice, Second Edition. Boston: Allyn and Bacon

Sugiyono, Prof. Dr. 2010. Metode Penelitian Kuantitatif dan Kualitatif. Bandung : Alfabeta

Trianto. 2007. Model-Model Pembelajaran Inovatif Berorientasi Konstruktivistik. Surabaya: Rineka Cipta

Farid Zain, Ahmad. 2012. "Upaya Meningkatkan Hasil Belajar Matematika Melalui Penerapan Model Pembelajaran Kooperatif Tipe STAD Pada Pokok Bahasan Sistem Persamaan Linier Dua
Variabel pada Siswa Kelas X MM 3 Mahardika Surabaya Tahun Pelajaran 2012/2013”. Skripsi. Universitas PGRI Adi Buana Surabaya

Jazuli, Muhammad. 2012. "Pengaruh Penerapan Pembelajaran Kooperatif Tipe STAD Dengan Metode Diskusi Terhadap Prestasi Belajar Siswa Pada Pokok Bahasan Sistem Persamaan Linier Dua Variabel di Kelas VIII D SMP Negeri 48 Surabaya Tahun Pelajaran 2012/2013”. Skripsi. Universitas PGRI Adi BUana Surabaya

Ili La (2007) "Penerapan Model Pembelajaran Kooperatif Tipe STAD untuk Materi Persegi Panjang dan Persegi di Kelas VII SMP Kartika VII-6 Kendari”. Hasil penelitiannya menunjukkan bahwa model pembelajaran kooperatif tipe STAD dapat meningkatkan hasil belajar siswa. Jurnal matematika Universitas Negeri Surabaya.

(http://www.tulisansingkatimal.blogspot.com/2013/06/ht $\mathrm{ml} /$ Pembelajaran matematika menurut para ahliahli). Diakses tanggal 07 Agustus 2014 pukul 15.30

(http://www.dadangjsn.blogspot.com/2013/02/html/ Pengertian/Definisi Pendekatan Saintifik). Diakses tanggal 16 Juli 2014 pukul 09.26

(http://www.rujukanskripsi.blogspot.com/2013/03/html/ Kajian Teori : HAKIKAT HASIL BELAJAR MATEMATIKA). Diakses tanggal 07 Agustus 2014 pukul 15.06

(httpyAwww.tulisansingkatimal.blogspot.com/2011/05/h tml/ Model Pembelajaran Kooperatif Tipe STAD). Diakses tanggal 16 Juli 2014 pukul 09.18

(http://www.skripsiani.blogspot.com/2012/07/html/ Metode penelitian dan kajian teoritis). Diakses tanggal 07 Agustus 2014 pukul 15.54 